\title{
Okulöncesi Öğretmen Adaylarının Farklılaştırılmış Öğretim Konusundaki Öz-yeterliklerine İlişkin Görüşleri
}

\section{The Viewpoints of Preschool Teacher Candidates on Their Self-Efficiency Levels in Differentiated Education}

\begin{abstract}
Sevim AŞiROĞLU*
Öz: $\mathrm{Bu}$ araştırmanın amacı, bir vakıf üniversitesinin eğitim fakültesinde öğrenim görmekte olan okulöncesi öğretmen adaylarının farklılaştırılmış öğretimle ilgili öz-yeterlik düzeylerine ilişkin görüşlerini ortaya koymaktır. Araşırmada tarama modeli kullanılmıştır. Araştırma evrenini 2015-2016 Eğitim-Öğretim yılında İstanbul ilindeki bir vakıf üniversitesinde okul öncesi öğretmenliği bölümünde öğrenim gören 120 okul öncesi öğretmen adayı oluşturmaktadır. Gönüllü olan 96 öğretmen adayının tümü örnekleme dâhil edilmiştir. Araştırmada nicel veri analizi kullanılmış olup, veriler araştırmacı tarafindan geliştirilen "Farklılaştırılmış Öğretim Anketi" yoluyla toplanmıştır. Araştırmada veriler SPSS 16.0 paket programında frekans, yüzde, aritmetik ortalama ve ki-kare ile analiz edilmiştir. Araştırmanın sonucuna göre okulöncesi öğretmen adayları kendilerini farklılaştııılmış öğretimle ilgili konulla ilgili çoğunluğunla yeterli bulmaktadır. Üst düzey öğrencilere öğrenme faaliyetleri hazırlayabilme, her düzeydeki öğrenciye göre dersi basamaklayabilme, öğrencilerin tümünü motive edebilme, öğrencilerin görüşünü alarak plan hazırlayabilme konularında ise kendilerini yetersiz görmektedirler. Üst düzey öğrencilere öğrenme faaliyetleri hazırlayabilme, her düzeydeki öğrenciye göre dersi basamaklayabilme, öğrencilerin tümünü motive edebilme, öğrencilerin görüşünü alarak plan hazırlayabilme konularında kendilerini yetersiz görmektedirler. Okulöncesi öğretmen adaylarının farklılaştırılmış öğretimle ilgili seminere, konferansa vb. eğitimlere katılıp katılmama ve kitap-yayın okuyup okumama durumuna göre farklılaştırılmış öğretime ilişkin öz-yeterlikleri arasında, bazı konularda anlamlı farklılıklar gösterdiği görülmüştür. Araştırmada okulöncesi öğretmen adaylarına, farklılaştırılmış öğretimle ilgili kendilerini yetersiz hissettikleri konularda programlar geliştirmesi önerilmektedir.

Anahtar Kelimeler: Farklılaştırılmış öğretim, öğretmen eğitimi programı, okulöncesi eğitimi
\end{abstract}

\begin{abstract}
The purpose of this study is to investigate and reveal the self-efficiency levels of the preschool teacher candidates studying at the Educational Faculty of a Foundation University in Differentiated Education based on their viewpoints. The Scanning Method was used in this study. The universe of the study consists of the 120 preschool teacher candidates studying at the Educational Faculty of a Foundation University in Istanbul in 2015-2016 Academic year. 96 volunteering teacher candidates were included in the study. The Quantitative Data Analysis was used in the study, and the data were collected with the "Differentiated Education Questionnaire", which was developed by the author of the study. The data in the study were analyzed with frequency, percentage, arithmetic averages, and Chi-Square. According to the results of the study, the preschool teacher candidates consider themselves as sufficient in many of the items of Differentiated Education. They find themselves as being insufficient in some parts of the application of the Differentiated Education. They consider themselves as being insufficient in items such as preparing educational activities for upper-level students, layering the class according to students from each level, motivating all students, preparing plans by receiving the opinions of the students. There were significant differences between the status of the preschool teacher candidates according to receiving seminars, conferences, etc. on Differentiated Education, having read books-publications, and using selfefficiency in Differentiated Education. The topics in which the preschool teacher candidates feel themselves as being insufficient must be provided in the curriculum.
\end{abstract}

Keywords: Differentiated education, curriculum of teacher training, preschool education 


\section{Giriş}

Her çocuk birbirinden farklıdır. Herbiri farklı aile kültürlerine, farklı ön bilgilere ve farklı kişisel özelliklere sahiptir. Bu yüzden öğrencilerin bireysel farklıklarını dikkate alabilmek için öğretimin her öğrenci için farklılaştırıması gerekir. Son y1llarda geliştirilen programların (Milli Eğitim Bakanlığı [MEB], 2013) yapılandırmacılığa dayalı olması sebebiyle bireysel farklılıklara göre yapılan öğretim ön plana çıkmaktadır. Programlarda öğretim süreci öğrencilerin ilgilerine ve ihtiyaçlarına göre düzenlenmektedir ve öğrenci aktif kılınmaktadır. Ayrıca her öğrencinin öğrenme yolu, öğrenme ilgisi, öğrenme hızı farklı olduğu görüşü hâkimdir.

Yeni MEB programlarının paradigması ile örtüşen yaklaşımlardan biri farklılaştırılmış öğretimdir. Farklılaştırılmış öğretim öğrencilerin farklı bireysel özellikleri olduğunu varsayan, bu özelliklere uygun öğrenme etkinlikleri geliştirerek her bireye başarılı olma firsatı tanıyan ve öğrenme sürecinde öğrencilerin öz-düzenleme, problem çözme, iletişim kurma, bilişüstü becerilerinin geliştirilmesini amaçlayan bir öğrenme yaklaşımıdır (Heacox, 2002). Başka bir ifade ile öğrencilerin bilgi, kavram, okuma, dil, öğrenme öncelikleri, ilgileri vb. özelliklerini tanıma; aynı sınıftaki farklı becerilere sahip öğrenciler için uygun öğrenme ve öğretim yaklaşımlarını kullanma; her öğrencinin bireysel başarılarını ve öğrenmelerini en üst düzeye çıkaracak etkinlikler planlama şeklinde tanımlanabilir. Planlama yapılırken öğrencilerin ön bilgileri tespit edilir, daha sonra sistematik bir şekilde içerik, süreç ve ürün farklılaştırılır. Öğretim sonunda ise toplam bir değerlendirme yapılarak öğretim sürecinin etkililiği hakkında bilgi edinilir (Hall, 2002). Tomlinson'a (2001) göre farklılaştırılmış öğretim üç karakteristik özelliğe göre farklılaşmaktadır. Bunlar; öğrencinin hazırbulunuşluğu, ilgisi ve öğrenme profilidir. Hazırbulunuşluk, öğrencilerin öğrenme-öğretme sürecine girmeden önce sahip oldukları yetenek ve becerileridir. İlgi, öğrencilerin derste verilen görevlere karşı merak duymasıdır. Öğrenme profili ise öğrencinini, öğrenme biçimi ifade eder. Öğretmenler programın tüm öğelerini bu üç özelliğe göre farklılaştırmalıdırlar.

Farklılaştırılmış öğretim heterojen sınıf ortamında, öğrencilerin öğrendiklerini göstermek için seçimler yapabildikleri bir öğrenme yaklaşımıdır (Chapman ve King, 2003). Bu yaklaşım sınıftaki her öğrencinin öğrenme deneyimlerine ve beceri düzeylerine uygun olarak öğretim yapılması düşüncesine dayanmaktadır (Smutny, 2003). Karadă̆ (2010) ise farklılaştırılmış öğretim modeli tasarladığ görevlerin bireysel farklılıklara göre olması gerektiğini ileri sürmüştür.

Tomlinson (2001) farklılaştırılmış öğretimle ilgili yanlış algıları ortadan kaldırmak için bazı görüşler öne sürmüşür:

- Farklılaştırılmış öğretim bir strateji değildir, bir paradigmadır. Programa eklenebilecek bir araç değildir.

- Farklılaştırılmış öğretim, öğretimin bireyselleştirilmesinden farklıdır. Bireyselleştirilmiş öğretimde her birey için ayrı bir program hazırlanır.

- Farklılaştırılmış öğretim sınıfta disiplinsizliği yol açmaz. Bu sınıflara öğretmen daha güçlü bir lider olarak durur ve çoklu etkinliklerin uygulanmasını yürütür, öğrencilerin öğrenme sorumluluğu almasına rehberlik eder.

- Farklılaştırılmış öğretimde sınıf homojen gruplara ayrılmaz. Benzer yetenek, ilgi ve öğrenme profiline sahip öğrencilerin biraraya geldiği gruplar oluşturulmaya çalış1lmaz, esnek gruplar vardir.

Farklılaştırılmış öğretimde değerlendirme tanısaldır. Değerlendirmede amaç öğrencilerin ilgi, beceri, öğrenme profili ile ilgili verilerin toplanmasıdır. Amaç öğrencilerin neleri öğrendiğini tespit etmek değildir, öğretimi yönlendirmektir. Yani değerlendirme öğretimin önemli bir parçasıdır (Tomlinson, 2005).

Prater (2003), öğretmenlere farklılaştırılmış öğretimin uygulanması için dikkat etmeleri gereken tavsiyeler öne sürmüştür. Buna göre öğretmenler farklılaştırmayı içerik, süreç ve ürün boyutlarında yapmalıdırlar. Öğretmenler; öğrencilerine ilgi göstermelidir, öğrencilerin güçlü 
yönünü ortaya çıkartmalıdırlar, yetersizlik gösteren öğrencilerin çabalamalarını teşvik etmeli ve onlara güvenmelidirler. Ayrıca eğitim programı, kurallar, öğretim, materyalleri, çevre özellikleri bakımından gözlemler yapıp, araştırmalıdır.

Öğretmen yeterliği, bir öğretmenin, öğrenme güçlüğü çeken öğrencilerde bile başarıyı yakalayabileceğine dair inancıdır (Woolfolk, 1998). MEB (2008) tarafından öğretmen yeterlikleri branşlara göre özel alan yeterlikleri şeklinde belirlenmiştir. Özel alan yeterlikleri arasında öğrencilerin kendi öğrenmelerini kendilerinin inşa edebilmelerine yardımcı olabilecek planlamalar yapma, materyaller hazırlama, eğitim süreci yürütme gibi yeterlikler ise farklılaştırılmış öğretim paradigmasını anımsatmaktadır. Öğretmenlerin farklılaştırılmış öğretim konusunda yeterlilikleri henüz göreve başlamadan önce bilinmesi farklılaştırılmış öğretimin tam olarak uygulanması için önemli bir bilgidir. Yabaş ve Altun, (2009) öğretmenlerin farklılaştırılmış öğretim tasarımını daha çok kullanmaları gerekliliğine işaret etmektedir. Bunun için öğretmenlere, hizmet öncesi ve hizmet içi eğitimlerde farklılaştırılmış öğretimin kullanım alanları, ilkeleri, teknikleri, olumlu ve sınırlı yönleri ile ilgili bilgi verilmelidir. Öğretmenlere verilecek eğitimden önce ihtiyaç analizi niteliği taşıyan bilimsel araştırmalara ihtiyaç duyulmaktadır.

Öğretmenler, sınav sonuçları ile başarı düzeylerini belirlediği için, öğrencileri sınavlara hazırlayabileceğine inandıkları stratejileri tercih etmektedirler. Bu stratejileri kullanmak öğrencilerin bireysel ihtiyaçlarına yönelmek yerine, grubun genel ihtiyaçlarına hitap eden ve herkese uyacağ düşünülen tek tip bir öğretim düzeyinin ele alınmasına yol açmıştır (Bravmann, 2004). Ülkemizde özellikle kitlesel sınavların yaygın oluşu bu anlayışın sürmesine sebep olmaktadır. Bunun yanısıra öğrencilerin yaratıcılıkları, üstbilişsel becerileri, yetenekleri dikkate alınmamaktadır.

Türkiye'de farklılaştırılmış öğretim konusunda bilimsel araştırmalarla ilgili önemli bir boşluk söz konusudur. Ülkemizde bu konuda yapılan çalışmaların yetersizliği, bu konuda yapılacak çalışmalarda farklılaştırılmış öğretimin farklı öğrenme düzeylerinde ve çalışma gruplarında öğrencilerin akademik başarılarını artırma ve farklılaştırılmış öğretim yaklaşımına ilişkin öğretmen, öğrenci, veli, yönetici görüşlerinin belirlenmesini amaçlayan çalışmaların yapılabileceğini düşündürmektedir. Genelde farklılaştırılmış öğretimle ilgili araştırmalar öğretmenlerin algılarının ölçülmesine, öğrenciler üzerindeki etkisi üzerinde çalışılmıştır (Karadağ, 2014). Bu araştırma ise bireysel farklılıkların en çok önem arz ettiği okulöncesi eğitim kurumlarında görev alacak okulöncesi öğretmen adayları ile yürütülmüştür.

$\mathrm{Bu}$ araştırmanın amacı, bir vakıf üniversitesinin eğitim fakültesinde öğrenim görmekte olan okulöncesi öğretmen adaylarının farklılaştırılmış öğretimle ilgili öz-yeterlilik düzeylerini kendi görüşlerine göre ortaya koymaktır. $\mathrm{Bu}$ amaç doğrultusunda aşağıdaki sorulara cevaplar aranmıştır:

1. Okulöncesi öğretmen adaylarının farklılaştırılmış öğretim konusundaki öz-yeterliklerine ilişkin görüşleri nedir?

2. Okulöncesi öğretmen adaylarının farklılaştırılmış öğretim konusundaki öz-yeterliklerine ilişkin görüşleri arasında sınıf seviyelerine göre farklılıklar var mıdır?

3. Okulöncesi öğretmen adaylarının farklılaştırılmış öğretim alanında eğitim alıp alamadıklarına göre farklılaştırılmış öğretim konusundaki öz-yeterliklerine ilişkin görüşleri arasında anlamlı farklılıklar var midır?

4. Okulöncesi öğretmen adaylarının farklılaştırılmış öğretim alanındaki kitapları ve yayınları okuyup, okumadıklarına göre farklılaştırılmış öğretim konusundaki öz-yeterliklerine ilişkin görüşleri arasında anlamlı farklılıklar var mıdır?

Araştırmada elde edilecek sonuçların, öğretmenlere ve alanda çalışacak olan akademisyenlere faydalı bilgiler sağlayacağı düşünülmektedir. Özellikle okulöncesi öğrencilerine yönelik eğitimin önem kazandığı bugünlerde farklılaştırılmış öğretimi kullanacak okulöncesi eğitimindeki öğretmen adaylarının öz-yeterliklerinin bilinmesi eğitim sisteminin parçası olan birçok kişiye ve kuruma yol gösterebilir. 


\section{Yöntem}

Araştırmada okulöncesi öğretmen adaylarının farklılaştırılmış öğretime ilişkin varolan özyeterlikleri tespit edilmeye çalışıldığı için tarama modeli kullanılmıştır. Tarama modeli bir grubun belirli özelliklerini belirlemek için verilerin toplanmasını amaçlayan araştırmalardır (Karasar, 2005).

\section{Örneklem}

Bu araştırmanın çalışma evrenini 2015-2016 Eğitim-Öğretim yılında İstanbul ilindeki bir vakıf üniversitesinde Okul öncesi öğretmenliği bölümünde öğrenim gören 120 okulöncesi öğretmen adayı oluşturmaktadır. Gönüllü olan 96 öğretmen adayının tümü örnekleme dâhil edilmiştir. Daha önce "Öğretim İlke ve Yöntemleri" dersini aldıkları için sadece 3. ve 4. sinıflar örnekleme dâhil edilmiştir. Bu durumda Örneklem grubunda 34 kişi üçüncü sınıfta, 62 kişi dördüncü sinıfta öğrenim görmektedir.

\section{Veri toplama}

Araştırmada nicel veri analizi kullanılmış olup, veriler araştırmacı tarafından geliştirilen "Farklılaştırılmış Öğretim Anketi" yoluyla toplanmıştır. Anket için ilgili alanyazın, uzman kanısı ve ön uygulama sonuçları doğrultusunda geçerlilik ve güvenirlik çalışmaları yapılmıştır. Buna göre okulöncesi öğretmen adaylarının farklılaştııılmış öğretime ilişkin öz-yeterliklerini saptamak için ilk olarak konu alanı ile ilgili alan yazın çalışması yapılmıştır. Anket maddelerinin yazılmasında farklılaştırılmış öğretime yönelik öğretmen yeterliğini ölçmek amacıyla geliştirilmiş ölçek, test, anket ve çeşitli araştırma sonuçları incelenmiştir. Bu araştırmalardan Çam'ın (2013) öğretmenlerin yetkinliklerini ölçmek için geliştirdiği ölçeği; motivasyon, materyal, öğrenme ortamı, bireysel farklılıklar, görevler, değerlendirme şeklinde boyutlarından oluşmaktadır. Whipple (2012) ise öğrencilerin ilgileri, ders planı, içerik, süreç, ürün ve değerlendirme boyutlarından oluşan farklılaştırılmış öğretime yönelik öğretmen algısı ve uygulamaları ölçeği geliştirmiştir. Uzman görüşü alındıktan sonra pilot uygulama için bir grup gönüllü öğretmenler ile birebir görüşmeler yapılmıştır. Görüşmelerde öğretmenlere farklılaştırılmış ögretimi kullanma düzeylerini belirleyecek açık uçlu sorular yöneltilmiştir.

Anketin birinci bölümü kişisel bilgi formudur. Kişisel bilgi formu sınıf seviyesi, farklılaştırılmış öğretimle ilgili eğitime katılma durumu, konuyla ilgili kitap/yayın okuma durumu gibi bilgiler içermektedir. İkinci bölümde ise farklılaştırılmış öğretime ilişkin özyeterlikleri belirlemeyi amaçlayan 17 soruluk bir anket bulunmaktadır. Anket "Hayır" (1), "Biraz" (2), "Evet” (3) şeklinde 3'lü olarak derecelendirilmiştir. Ankette her bir madde birbirinden bağımsız bir şekilde ele alınıp, değerlendirilmiştir. Bu sebeple testin güvenirliğiyle ilgili Cronbach Alfa iç tutarlık katsayısı gibi bir analiz kullanılmamıştır.

\section{Verilerin analizi}

Araştırmada veriler SPSS 16.0 paket programında frekans, yüzde, aritmetik ortalama ve ki-kare ile analiz edilmiştir. Ki-kare bağımsızlık testi, iki kategorik değişkenin, birbirine bağımlı olup olmadığını test etmek için kullanılır (Büyüköztürk, 2002). Bu araştırmada ise sınıf seviyesi, farklılaştırılmış öğretimle ilgili konfrerans, seminer vb yoluyla eğitim alma ve yayın, kitap okuma durumu değişkenlerinin farklılaştırılmış öğretime ilişkin öz-yeterlik açısından anlamlı bir farklılık gösterip göstermediği tespit edilmeye çalışıldığı için ki-kare testinden yararlanılmıştır.

\section{Bulgular}

\section{Okulöncesi öğretmen adaylarının öz-yeterliklerinin dağılımına ilişskin bulgular}

Okulöncesi öğretmen adaylarının öz-yeterliklerinin dağılımına ilişkin bulgular Tablo 1'de verilmiştir. 
Tablo 1. Okulöncesi Öğretmen Adaylarının Öz-Yeterliklerinin Dağılımı

\begin{tabular}{|c|c|c|c|c|c|c|c|}
\hline No & Maddeler & \multirow{2}{*}{$\frac{\text { Evet }}{N}$} & \multicolumn{3}{|c|}{ Biraz } & \multicolumn{2}{|c|}{ Hayır } \\
\hline \multirow[b]{2}{*}{1} & \multirow{2}{*}{$\begin{array}{l}\text { Dersteyken her öğrenciye değerli olduğunu } \\
\text { hissettirebilirim. }\end{array}$} & & $\% \quad \Lambda$ & c & 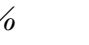 & $N$ & $\%$ \\
\hline & & 76 & 79,2 & 14 & 14,6 & 6 & 6,2 \\
\hline 2 & $\begin{array}{l}\text { Sınıftaki tüm öğrencileri eşit bir şekilde motive } \\
\text { edebilirim. }\end{array}$ & 42 & 43,8 & 18 & 18,8 & 36 & 37,5 \\
\hline 3 & $\begin{array}{l}\text { Farklı ilgi alanları, başarı düzeyleri,öğrenme hızlarına vb. } \\
\text { yönelik materyaller kullanabilirim. }\end{array}$ & 86 & 89,6 & 8 & 8,3 & 2 & 2,1 \\
\hline 4 & $\begin{array}{l}\text { Sinıfta farklı ilgi alanlarına ve ihtiyaçlara göre öğrenme } \\
\text { köşeleri oluşturabilirim. }\end{array}$ & 72 & 75 & 14 & 14,6 & 10 & 10,4 \\
\hline 5 & $\begin{array}{l}\text { Planlarımı öğrencilerin görüşlerini alarak } \\
\text { hazırlayabilirim. }\end{array}$ & 46 & 47,9 & 36 & 10,4 & 14 & 14,6 \\
\hline 6 & $\begin{array}{l}\text { Öğrencilerin ihtiyaçlarına göre yaptığım öğretimin hızını } \\
\text { belirleyebilirim. }\end{array}$ & 62 & 64,6 & 20 & 20,8 & 14 & 14,6 \\
\hline 7 & $\begin{array}{l}\text { Dersimi her düzeydeki öğrenciye göre basamaklara } \\
\text { ayırabilirim. }\end{array}$ & 42 & 43,8 & 30 & 31,2 & 24 & 25 \\
\hline 8 & $\begin{array}{l}\text { Etkinlikleri hazırlarken her öğrencinin öğrenme hızını } \\
\text { dikkate alan faaliyetler yapabilirim. }\end{array}$ & 58 & 60,4 & 16 & 16,7 & 22 & 22,9 \\
\hline 9 & $\begin{array}{l}\text { Yavaş öğrenen ama gayret gösteren öğrencileri öğrenme } \\
\text { düzeylerini arttıracak çalışmalara yönlendirirebilirim. }\end{array}$ & 68 & 70,8 & 18 & 18,8 & 10 & 10,4 \\
\hline 10 & $\begin{array}{l}\text { Üst düzey öğrenciler için öğrenme faaliyetleri } \\
\text { planlayabilirim. }\end{array}$ & 36 & 37,4 & 28 & 29,2 & 32 & 33,3 \\
\hline 11 & $\begin{array}{l}\text { Yavaş öğrenen ama gayret gösteren öğrenciler için } \\
\text { öğrenme faaliyetleri planlayabilirim. }\end{array}$ & 70 & 72,9 & 22 & 22,9 & 4 & 4,2 \\
\hline 12 & $\begin{array}{l}\text { Öğrencilerin bireysel ihtiyaçları için özel görevler } \\
\text { verebilirim. }\end{array}$ & 76 & 79,2 & 10 & 10,4 & 10 & 10,4 \\
\hline 13 & $\begin{array}{l}\text { Öğrencileri bir konuda derinlemesine çalışmalarını } \\
\text { sağlayacak görevlere yönlendirebilirim. }\end{array}$ & 72 & 75 & 20 & 20,8 & 4 & 4,2 \\
\hline 14 & $\begin{array}{l}\text { Öğrencilerimi farklı disiplinleri birarada } \\
\text { kullanabilecekleri gerçek yaşam problemleri üzerinde } \\
\text { çalışmalarını sağlayabilirim. }\end{array}$ & 62 & 64,6 & 26 & 27,1 & 8 & 8,3 \\
\hline 15 & $\begin{array}{l}\text { Farklı zekâya, bilgiye, başarıya vb. göre seviye grupları } \\
\text { oluşturabilirim. }\end{array}$ & 62 & 64,6 & 24 & 25,0 & 10 & 10,4 \\
\hline 16 & Farklı değerlendirme yöntemlerini birlikte kullanabilirim. & 74 & 77,1 & 18 & 18,8 & 4 & 4,2 \\
\hline 17 & $\begin{array}{l}\text { Yeni bir konuyu öğrenmeden önce öğrencilerimin } \\
\text { hazırbuluşluklarını ortaya çıkarabilecek değerlendirmeler } \\
\text { yapabilirim. }\end{array}$ & 82 & 85,4 & 10 & 10,4 & 4 & 4,2 \\
\hline
\end{tabular}

Tablo 1'de görüldüğü gibi, okulöncesi öğretmen adaylarının farklılaştırılmış öğretim konusundaki öz-yeterliklerinin dağılımına ilişkin 3. maddede belirtilen "Farklı ilgi alanları, başarı düzeyleri, öğrenme hızlarına vb. yönelik materyaller kullanabilirim." 89,6's1, 17. maddede belirtilen "Yeni bir konuyu öğrenmeden önce öğrencilerimin hazırbuluşluklarını ortaya çıkarabilecek değerlendirmeler yapabilirim." 85,4's1, 1. maddede belirtilen "Dersteyken her öğrenciye değerli olduğunu hissettirebilirim." 79,2'si, 12. maddede belirtilen "Öğrencilerimin bireysel ihtiyaçları için özel görevler verebilirim" 79,2'si "evet"; 10. maddede belirtilen "Üst düzey öğrenciler için öğrenme faaliyetleri planlayabilirim." 37,4 ü, 7. maddede belirtilen "Dersimi her düzeydeki öğrenciye göre basamaklara ayırabilirim." 43,8'i, 2. maddede belirtilen "Sınıftaki tüm öğrencilerimi eşit bir şekilde motive edebilirim" 43,8'i, 5. maddede belirtilen "Planlarımı öğrencilerin görüşlerini alarak hazırlayabilirim." 47,9'u "evet" şeklinde görüş belirtmişlerdir.

Bulgulardan hareketle okulöncesi öğretmen adaylarının; üst düzey öğrencilere yönelik öğrenme faaliyetleri hazırlama, her düzeydeki öğrenciye göre dersi basamakla, öğrencileri motive edebilme, öğrencilerin görüşünü alarak plan hazırlayabilme konularında kendilerini düşük düzeyde yeterli gördükleri söylenebilir. Öğretmen adayları bunların dışında kalan 
maddelerde kendilerini yeterli bulmaktadır. Özellikle farklı özelliklerdeki öğrenciler için materyal hazırlama ve görev verme, ön bilgilerin değerlendirilmesi, tüm öğrencilere değerli olduğunu hissetirebilme konularında kendilerini oldukça yeterli bulmaktadırlar.

Sınıf seviyelerine göre, okulöncesi ö̆ğretmen adaylarının farklılaştırılmış öğretim ile ilgili özyeterliklerine ilişsin bulgular

Sınıf seviyelerine göre, okulöncesi öğretmen adaylarının farklılaştırılmış öğretim ile ilgili özyeterliklerine ilişkin bulgular Tablo 2'de verilmiştir.

Tablo 2. Sinıf Seviyelerine Göre, Okulöncesi Öğretmen Adaylarının Farklılaştırılmış Öğretim Ile İlgili Öz-Yeterliklerine İlişkin Bulgular

\begin{tabular}{|c|c|c|c|c|c|c|c|c|c|}
\hline $\begin{array}{l}\text { Madde } \\
\text { No }\end{array}$ & Sinif & & Evet & Kismen & Hayır & Toplam & $\chi^{2}$ & sd & $\mathrm{p}$ \\
\hline \multirow{6}{*}{13} & \multirow[b]{2}{*}{ 4.sinıf } & $\mathrm{N}$ & 18 & 12 & 4 & 34 & \multirow{6}{*}{7,99} & \multirow{6}{*}{2} & \multirow{6}{*}{0,01} \\
\hline & & $\%$ & 18,8 & 12,5 & 4,2 & 35,4 & & & \\
\hline & & $\mathrm{N}$ & 54 & 8 & 0 & 62 & & & \\
\hline & 3.sinif & $\%$ & 56,3 & 8,3 & 0,0 & 64,6 & & & \\
\hline & \multirow{2}{*}{ Toplam } & $\mathrm{N}$ & 72 & 20 & 4 & 96 & & & \\
\hline & & $\%$ & 75,0 & 20,8 & 4,2 & 100,0 & & & \\
\hline \multirow{6}{*}{14} & \multirow{2}{*}{$4 . \sin 1 f$} & $\mathrm{~N}$ & 14 & 14 & 6 & 34 & \multirow{6}{*}{6,9} & \multirow{6}{*}{2} & \multirow{6}{*}{0,03} \\
\hline & & $\%$ & 14,6 & 14,6 & 6,3 & 35,4 & & & \\
\hline & $3 \sin 1 f$ & $\mathrm{~N}$ & 48 & 12 & 2 & 62 & & & \\
\hline & 3.sinit & $\%$ & 50,0 & 12,5 & 2,1 & 64,6 & & & \\
\hline & \multirow{2}{*}{ Toplam } & $\mathrm{N}$ & 62 & 26 & 8 & 96 & & & \\
\hline & & $\%$ & 64,6 & 27,1 & 8,3 & 100,0 & & & \\
\hline
\end{tabular}

Tablo 2'de görüldüğ̈̈ gibi, sınıf seviyelerine göre okulöncesi öğretmen adaylarının belirtilen malddelerde farklılaştırılmış öğretim konusundaki öz-yeterliklerine ilişkin görüşleri arasında anlamlı farklılaşma görülmüştür $\left(\chi 2(13)=7,99 ; \chi^{2}(14)=6,9 \mathrm{p} \leq 0.05\right)$. Buna göre, "Bir konuda derinlemesine çalışmalarını gerektirecek çalışmalara yönlendirebilirim." şeklinde belirtilen 13. maddeye; dördüncü sınıfta öğrenim gören okulöncesi öğretmen adaylarının \% 56,3'ü, üçüncü sınıfta öğrenim gören okulöncesi öğretmen adaylarının \% 18,8'i “evet”; "Öğrencilerimin farklı disiplinleri birarada kullanabilecekleri gerçek yaşam problemleri üzerinde çalışmalarını sağlayabilirim." şeklinde belirtilen 14. maddeye; dördüncü sınıfta öğrenim gören okulöncesi öğretmen adaylarının \% 50'si, üçüncü sınıfta öğrenim gören okulöncesi öğretmen adaylarının \% 14,6's1 "evet”, görüşüne katılım gösterdikleri görülmüştür.

Bulgulardan hareketle dördüncü sınıfta öğrenim gören okulöncesi öğretmen adaylarının üçüncü sınıfta öğrenim görenlere göre; öğrencilere, farklılaştırılmış öğretimin gerektirdiği görevler verme ve gerçek yaşam problemlerini içeren çalışmalara yönlendirme konularında kendilerini daha yüksek düzeyde yeterli gördükleri söylenebilir.

Konferansa, seminer, kurs vb. ĕgitimlere katılıp katılmadıklarına göre, okulöncesi öğretmen adaylarının farklılaştırılmuş öğretimi öğretim ile ilgili öz-yeterliklerine iliş̧kin bulgular

Konferans, seminer, kurs vb. eğitimlere katılıp katılmadıklarına göre, okulöncesi öğretmen adaylarının farklılaştırılmış öğretim ile ilgili özyeterliliklerine ilişkin bulgular Tablo 3'de verilmiştir.

Tablo 3'de görüldüğü gibi, farklılaştırılmış öğretim konusunda konferansa, seminer vb. eğitimlere katılıp katılmadıklarına göre, okulöncesi öğretmen adaylarının farklılaştırılmış öğretim konusundaki öz-yeterlikleri ile ilgili görüssleri arasında anlamlı farklılaşma görülmüştür $\left(\chi^{2}(5)=3,6 ; \chi^{2}(10)=8,35 ; \chi^{2}(11)=8,91 ; \chi^{2}(14)=2,21 ; \chi^{2} \mathrm{p} \leq 0.05\right)$. Buna göre, "Planlarım1 öğrencilerin görüşlerini alarak hazırlayabilirim." şeklinde belirtilen 5. maddeye eğitim alan okulöncesi öğretmen adaylarının \%27,8'i "evet”, \% 25'i "bazen”, \% 4,17'si "hayır"; eğitim almayan ögretmen adaylarının \%10,42'i "evet", \% 22,92'si "bazen", \% 10,42'si "hayır"; "Üst düzey öğrenciler için öğrenme faaliyetleri planlayabilirim" şeklinde belirtilen 10. maddeye eğitim alan okulöncesi öğretmen adaylarının \% 20,83'ü “evet”, \% 18,75'i "bazen”, \% 10,42'si 
"hayır"; eğitim almayan öğretmen adaylarının \% 8,33'i “evet”, \% 18,75'i "bazen", \% 22,95'i "hayır"; "Yavaş öğrenen ama gayret gösteren öğrenciler için öğrenme faaliyetleri planlayabilirim." şeklinde belirtilen 11. maddeye eğitim alan okulöncesi öğretmen adaylarının \% 41,67'si "evet", \% 16,67'si "bazen", \% 0'1 "hayır"; eğitim almayan öğretmen adaylarının \%31,25'i "evet", \% 6,25'i "bazen", \% 4,17'si "hayı"; "Öğrencilerimin farklı disiplinleri birarada kullanabilecekleri gerçek yaşam problemleri üzerinde çalışmalarını sağlayabilirim." şeklinde belirtilen 14. maddeye eğitim alan okulöncesi öğretmen adaylarının \% 35,42'si "evet", \% 18,75'i "bazen", \% 0'1 "hayır"; eğitim almayan öğretmen adaylarının \% 29,17'si "evet", \% 8,33’ü “bazen”, \% 8,33’ü "hayır” görüşüne kat1lım gösterdikleri görülmüştür.

Tablo 3. Konferans, Seminer, Kurs vb. Eğitimlere Katılıp Katılmadıklarına Göre, Okulöncesi Öğretmen Adaylarının Farklılaştırılmış Ögretim Ille İlgili Öz-Yeterliklerine İlişkin Bulgular

\begin{tabular}{|c|c|c|c|c|c|c|c|c|c|}
\hline \multirow[b]{2}{*}{ Madde } & \multirow{2}{*}{\multicolumn{2}{|c|}{$\begin{array}{c}\text { Seminer vb } \\
\text { Kat1lım } \\
\text { Durumu }\end{array}$}} & \multicolumn{4}{|c|}{ Özyeterlik Seviyeleri } & \multirow[b]{2}{*}{$\chi^{2}$} & \multirow[b]{2}{*}{$\mathrm{sd}$} & \multirow[b]{2}{*}{$\mathrm{p}$} \\
\hline & & & 1 & 2 & 3 & Toplam & & & \\
\hline \multirow{6}{*}{5} & & $\mathrm{~N}$ & 4 & 24 & 26 & 54 & \multirow{6}{*}{3,6} & \multirow{6}{*}{2} & \multirow{6}{*}{0,03} \\
\hline & Evet & $\%$ & 4,17 & 25 & 27,08 & 56,25 & & & \\
\hline & & $\mathrm{N}$ & 10 & 22 & 10 & 42 & & & \\
\hline & Hayır & $\%$ & 10,42 & 22,92 & 10,42 & 43,76 & & & \\
\hline & \multirow{2}{*}{ Toplam } & $\mathrm{N}$ & 14 & 46 & 36 & 96 & & & \\
\hline & & $\%$ & 14,58 & 47,92 & 37,5 & 100 & & & \\
\hline \multirow{6}{*}{10} & Г & $\mathrm{N}$ & 10 & 18 & 20 & 48 & \multirow{6}{*}{8,35} & \multirow{6}{*}{2} & \multirow{6}{*}{0,03} \\
\hline & Evet & $\%$ & 10,42 & 18,75 & 20,83 & 50 & & & \\
\hline & & $\mathrm{N}$ & 22 & 18 & 8 & 48 & & & \\
\hline & Hayır & $\%$ & 22,92 & 18,75 & 8,33 & 50 & & & \\
\hline & \multirow{2}{*}{ Toplam } & $\mathrm{N}$ & 32 & 36 & 28 & 96 & & & \\
\hline & & $\%$ & 16,67 & 18,75 & 14,58 & 50 & & & \\
\hline \multirow{6}{*}{11} & \multirow{2}{*}{ Evet } & $\mathrm{N}$ & 0 & 16 & 40 & 56 & \multirow{6}{*}{8,91} & \multirow{6}{*}{2} & \multirow{6}{*}{0,03} \\
\hline & & $\%$ & 0 & 16,67 & 41,67 & 58,34 & & & \\
\hline & Ночи. & $\mathrm{N}$ & 4 & 6 & 30 & 40 & & & \\
\hline & Hayir & $\%$ & 4,17 & 6,25 & 31,25 & 41,67 & & & \\
\hline & \multirow{2}{*}{ Toplam } & $\mathrm{N}$ & 4 & 22 & 70 & 96 & & & \\
\hline & & $\%$ & 4,17 & 22,92 & 72,92 & 100 & & & \\
\hline \multirow{6}{*}{14} & \multirow{2}{*}{ Evet } & $\mathrm{N}$ & 0 & 18 & 34 & 52 & \multirow{6}{*}{2,21} & \multirow{6}{*}{2} & \multirow{6}{*}{0,01} \\
\hline & & $\%$ & 0 & 18,75 & 35,42 & 54,17 & & & \\
\hline & & $\mathrm{N}$ & 8 & 8 & 28 & 44 & & & \\
\hline & Hayır & $\%$ & 8,33 & 8,33 & 29,17 & 45,83 & & & \\
\hline & \multirow{2}{*}{ Toplam } & $\mathrm{N}$ & 8 & 26 & 62 & 96 & & & \\
\hline & & $\%$ & 8,33 & 27,08 & 64,58 & 100 & & & \\
\hline
\end{tabular}

Bulgulardan hareketle farklılaştırılmış öğretim konusunda konferans, seminer, kurs vb yoluyla eğitim alan okulöncesi öğretmen adaylarının eğitim almayanlara göre öğrenci görüşüne, yavaş öğrenenlere ve üst düzey öğrencilere göre öğrenme faaliyetleri planlayabilme konularında kendilerini daha yüksek yeterli gördükleri söylenebilir. Ayrıca farklılaştırılmış öğretim konusunda konferans, seminer, kurs vb yoluyla eğitim alan öğretmen adaylarının eğitim almayanlara göre öğrencileri farklı disiplinlerin birarada kullanıldığı gerçek yaşam problemlerine yönlendirebilme konusunda kendilerini daha yüksek düzeyde yeterli görmektedirler.

Kitap/yayın okuyup okumadıklarına göre, okulöncesi öğretmen adaylarının farklılaştırılmış öğretim ile ilgili öz-yeterliklerine ilişkin bulgular

Kitap/yayın okuyup okumadıklarına göre, okulöncesi öğretmen adaylarının farklılaştırılmış öğretim ile ilgili öz-yeterliklerine ilişkin bulgular Tablo 4'de verilmiş̧ir. 
Tablo 4. Kitap/Yayın Okuyup Okumadıklarına Göre, Okulöncesi Öğretmen Adaylarının Farklılaştırllmuş Öğretim İle İlgili Öz-Yeterliliklerine İlişkin Bulgular

\begin{tabular}{|c|c|c|c|c|c|c|c|c|c|}
\hline \multirow[b]{2}{*}{ Madde } & \multirow{2}{*}{\multicolumn{2}{|c|}{$\begin{array}{l}\text { Kitap/yayin } \\
\text { okuma } \\
\text { durumu }\end{array}$}} & \multicolumn{4}{|c|}{ Özyeterlik Seviyeleri } & \multirow[b]{2}{*}{$x^{2}$} & \multirow[b]{2}{*}{ sd } & \multirow[b]{2}{*}{$\mathrm{P}$} \\
\hline & & & 1 & 2 & 3 & Toplam & & & \\
\hline \multirow{6}{*}{2} & & $\mathrm{~N}$ & 16 & 10 & 30 & 56 & \multirow{6}{*}{2,2} & \multirow{6}{*}{2} & \multirow{6}{*}{0,03} \\
\hline & okudu & $\%$ & 16,67 & 10,42 & 31,25 & 58,34 & & & \\
\hline & & $\mathrm{N}$ & 20 & 8 & 12 & 40 & & & \\
\hline & okumad1 & $\%$ & 20,83 & 8,33 & 12,5 & 41,66 & & & \\
\hline & \multirow{2}{*}{ Toplam } & $\mathrm{N}$ & 36 & 18 & 42 & 96 & & & \\
\hline & & $\%$ & 37,5 & 18,75 & 43,75 & 100 & & & \\
\hline \multirow{6}{*}{8} & & $\mathrm{~N}$ & 10 & 14 & 34 & 58 & \multirow{6}{*}{3,52} & \multirow{6}{*}{2} & \multirow{6}{*}{0,01} \\
\hline & okudu & $\%$ & 10,42 & 14,58 & 35,42 & 60,42 & & & \\
\hline & & $\mathrm{N}$ & 12 & 2 & 24 & 38 & & & \\
\hline & okumad1 & $\%$ & 12,5 & 2,08 & 25 & 39,58 & & & \\
\hline & & $\mathrm{N}$ & 22 & 16 & 58 & 96 & & & \\
\hline & & $\%$ & 22,92 & 16,67 & 60,42 & 100 & & & \\
\hline \multirow{6}{*}{10} & \multirow{2}{*}{ okudu } & $\mathrm{N}$ & 20 & 16 & 26 & 62 & \multirow{6}{*}{2,88} & \multirow{6}{*}{2} & \multirow{6}{*}{0,02} \\
\hline & & $\%$ & 20,83 & 16,67 & 27,08 & 64,58 & & & \\
\hline & Okumadi & $\mathrm{N}$ & 12 & 12 & 10 & 34 & & & \\
\hline & okumad1 & $\%$ & 12,5 & 12,5 & 10,42 & 35,42 & & & \\
\hline & \multirow{2}{*}{ Toplam } & $\mathrm{N}$ & 32 & 28 & 36 & 96 & & & \\
\hline & & $\%$ & 33,33 & 29,17 & 37,5 & 100 & & & \\
\hline \multirow{6}{*}{14} & \multirow{2}{*}{ okudu } & $\mathrm{N}$ & 2 & 16 & 40 & 58 & \multirow{6}{*}{2,32} & \multirow{6}{*}{2} & \multirow{6}{*}{0,03} \\
\hline & & $\%$ & 2,08 & 16,67 & 41,67 & 60,42 & & & \\
\hline & okumod & $\mathrm{N}$ & 6 & 10 & 22 & 38 & & & \\
\hline & okumadı & $\%$ & 6,25 & 10,42 & 22,92 & 39,59 & & & \\
\hline & \multirow{2}{*}{ Toplam } & $\mathrm{N}$ & 8 & & & 96 & & & \\
\hline & & $\%$ & 8,33 & 27,08 & 64,58 & 100 & & & \\
\hline
\end{tabular}

Tablo 4'de görüldüğü gibi, farklılaştırılmış öğretim konusunda kitap/yayın okuyup okumadıklarına göre, okulöncesi öğretmen adaylarının farklılaştırılmış öğretim konusundaki özyeterlikleri ile ilgili görüşleri arasında anlamlı farklılaşma görülmüştür $\left(\chi 2(2)=2,2 ; \chi^{2}(8)=\right.$ 3,$\left.52 ; \chi^{2}(10)=2,88 ; \chi^{2}(14)=2,32 ; p \leq 0.05\right)$. Buna göre, "Sınıftaki tüm öğrencilerimi eșit bir şekilde motive edebilirim." şeklinde belirtilen 2. maddeye farklılaştırılmış öğretimle ilgili kitap okuyan okulöncesi öğretmen adaylarının \% 31,25'i "evet”, \% 10,42'si "bazen", \% 16,67'si "hayır"; farklılaştırılmış öğretimle ilgili kitap okumayan öğretmen adaylarının \% 12,5'i "evet", \% 8,33'ü "bazen", \% 20,83'ü "hayır"; "Etkinlikleri hazırlarken her öğrencinin öğrenme hızını dikkate alacak faaliyetler yapabilirim." şeklinde belirtilen 8. maddeye okulöncesi öğretmen adaylarının \% 35,42'si "evet", \% 14,58'i "bazen", \% 10,42'si "hayır"; kitap okumayan öğretmen adaylarının \% 25'i “evet”, \% 2,08'i "bazen”, \% 12,5'i "hayır”;"Üst düzey öğrenciler için öğrenme faaliyetleri planlayabilirim." şeklinde belirtilen 10. maddeye eğitim alan okulöncesi öğretmen adaylarının \% 27,08'i "evet", \% 16'67'si "bazen", \% 12,5'i "hayır"; kitap okumayan öğretmen adaylarının \% 10,42'i "evet", \% 12'5'i "bazen", \% 12,5'i "hayır"; "Öğrencilerimin farklı disiplinleri birarada kullanabilecekleri gerçek yaşam problemleri üzerinde çalışmalarını sağlayabilirim." şeklinde belirtilen 14. maddede kitap okuyan okulöncesi öğretmen adaylarının \% 39,59'u "evet", \% 22,92'si "bazen", \% 2,08'i "hayır"; kitap okumayan öğretmen adaylarının \% 10,42'i “evet”, \% 22,92'si "bazen”, \% 6,25'i "hayır" görüşüne katılım gösterdikleri görülmüsşür.

Buradan hareketle farklılaştırılmış öğretim konusunda kitap-yayın vb. okuyan okulöncesi öğretmen adaylarının okumayanlara göre öğrencileri motive edebilme, her öğrencinin hızını dikkate alan faaliyetler yapabilme, üst düzey öğrenciler için öğrenme 
faaliyetleri planlayabilme, öğrencileri farklı disiplinlerin birarada kullanıldığı gerçek yaşam problemlerine yönlendirebilme konularında kendilerini daha yeterli gördükleri söylenebilir.

\section{Sonuç ve Öneriler}

Farklılaştırılmış öğretimle ilgili okulöncesi öğretmen adaylarının öz-yeterliklerini ortaya koymaya çalışan bu araştırmada tarama modeli kullanılmış olup, anket yoluyla nicel veriler toplanmıştır. Araştırmanın sonucuna göre okulöncesi öğretmen adayları kendilerini farklılaştırılmış öğretimle ilgili konuların büyük bir çoğunluğunda yeterli bulmaktadır.

$\mathrm{Bu}$ araştırmanın sonucu, öğretmen adaylarının öğretmenlik mesleği yeterliliğini araştıran Kahyaoğlu ve Yangın'ın (2007) araştırma sonucu ile paralellik göstermektedir. Kahyaoğlu ve Yangın'a (2007) göre öğretmen adayları kendilerini en çok "özel öğretime ihtiyaç duyan öğrencilere uygun öğretim yöntem ve tekniklerini uygulama" konusunda yeterli görmektedirler.

Farklılaştırılmış öğretimin uygulanması ile ilgili bazı konularda okulöncesi öğretmen adayları kendilerini yetersiz bulmaktadırlar. Üst düzey öğrencilere öğrenme faaliyetleri hazırlayabilme, her düzeydeki öğrenciye göre dersi basamaklayabilme, öğrencilerin tümünü motive edebilme, öğrencilerin görüşünü alarak plan hazırlayabilme konularında kendilerini yetersiz görmektedirler.

$\mathrm{Bu}$ araştırma okulöncesi öğretmen adaylarının sınıf düzeylerine göre farklılaştırılmış öğretimi kullanmaya yönelik öz-yeterlikleri arasında genel bir farklılaşma görülmememiş ancak bazı konularda 4. sınıflar lehine anlamlı farklılıklar gösterdiği görülmüştür. Dördüncü sınıf öğretmen adayları öğrencilere görevler verme ve onları gerçek yaşam problemlerine yönlendirme konusunda kendilerini daha fazla yeterli görmektedirler. Bu sonuç üzerinde etkili olabilecek nedenler alınan dersler arasındaki farklılıklar, ders veren öğretim elemanı farklılıklarında kaynaklanabilir.

Daha önce farklılaştırılmış öğretim konusunu içeren eğitimler alan okulöncesi öğretmen adayları, bu konuyla ilgili eğitim almayanlara göre öğrenci görüşüne göre planlar yapabilme konusunda kendilerini yeterli görmektedirler. Bu öğretmenler aynı zamanda gayret gösterdiği halde öğrenme güçlü çeken ve hızlı öğrenebilen üst düzey öğrencilere yönelik öğrenme faaliyetleri hazırlama, öğrencileri gerçek yaşam problemlerine yönlendirme konularında kendilerini daha fazla yeterli görmektedirler.

Farklılaştırılmış öğretim konusunda çeşitli yayınlar okuyan okulöncesi öğretmen adaylarının okumayanlara göre öğrencilerin tümünü eşit bir şekilde motive edebilme, her öğrencinin hızını dikkate alan faaliyetler yapabilme, üst düzey öğrenciler için öğrenme faaliyetleri planlayabilme, öğrencileri gerçek yaşam problemlerine yönlendirebilme konularında kendilerini daha yeterli gördükleri söylenebilir.

Araştırmada bazı gruplarda (3. sınıflar, kitap okumayanlar, eğitime katılmayanlar) ortak bulunan sonuç okulöncesi öğretmen adaylarının öğrencilere özel görev verme konusunda kendilerini yetersiz görmesidir. Araştırmanın bu sonucunu destekleyen bir başka araştırma Garcia (2011) tarafından yapılmıştır. Garcia (2011) öğretmenlerin farklılaştırılmış öğretimi uygulayabilmelerine ilişkin becerilerini incelemiştir ve öğretmenlerin en çok öğrencileri derinlemesine çalışma gerektiren görevlere yönlendirmede zorluk yaşadıkları sonucu bulunmuştur.

Araştırmalar farklılaştırılmış öğretimin başarı, bilişüstü beceri, yeterlik algısı, sözel davranışlar, bireysel ve sosyal gelişim vb. çeşitli değişkenler üzerindeki olumlu etkisi olduğu (Yabaş ve Altun, 2009; Lavender, 2009, Samms, 2009; Richards ve Omdal, 2007) ve öğretmenlerin farklılaştırılmış öğretimi desteklediği ama bilgi seviyelerinin yetersiz olduğu (Driskill, 2010; Ayers 2008) sonuçları üzerinde benzerlik göstermektedir. Bunlardan farklı olarak okulöncesi öğretmenlerinin farklılaştırılmış öğretimi nasıl kullandıklarını araştıran, Brennan (2008) öğretmenler tarafından öğrencilerin bireysel ihtiyaçlarının karşılandığını, ögrencilere rehberlik yapıldığını, öğretmenlerin plan hazırlamada zaman açısından sorun yaşadıklarını tespit etmiş̧tir. Okulöncesi öğretmen adayları ile yürütülen bu araştırmanın ise bir vakıf üniversitesindeki öğretmen adaylarının farklılaştırılmış öğretimin konularının büyük bir 
çoğunluğu ile ilgili öz-yeterliklerine ilişkin görüşlerinin olumlu olduğunu tespit edilerek literatüre katkı sağlayabileceği düşünülmektedir.

$\mathrm{Bu}$ araştırmanın önerileri şunlar olabilir:

Okulöncesi öğretmen adaylarına farklılaştırılmış öğretim konusunda kendilerini yetersiz hissettikleri konular ders içeriklerinde verilmelidir. Üst düzey öğrencilere öğrenme faaliyetlerinin nasıl hazırlayabilecekleri, her düzeydeki öğrenciye göre dersi nasıl basamaklayabilecekleri, öğrencilerin tümünü nasıl motive edebilecekleri, öğrencilerin görüşünü alarak nasıl planlar yapabilcekleri konuları özellikle "Öğretim İlke ve Yöntemleri, Bireysellleştirilmiş Öğretim Programı Geliştirme” derslerinin programları içerisinde özel olarak yer almalıdır.

Konferans, seminer, kurs vb yoluyla eğitim alan okulöncesi öğretmen adayları bazı konularda eğitim almalayanlara göre kendilerini daha yeterli gördükleri için; okulöncesi öğretmen adaylarına öğrenci görüşüne, yavaş öğrenenlere, üst düzey öğrencilere göre öğrenme faaliyetleri planlayabilmekonularında çeşitli organizasyonlar aracılığı ile uygulamalı eğitimler düzenlemelidir.

Okulöncesi öğretmen adayları öğrencileri motive edebilme, her öğrencinin hızını dikkate alan faaliyetler yapabilme, üst düzey öğrenciler için öğrenme faaliyetleri planlayabilme, öğrencileri farklı disiplinlerin birarada kullanıldığı gerçek yaşam problemlerine yönlendirebilme konularında kitap/yayın okumaya teşvik edilmelidir.

Okulöncesi öğretmen adayları uygulama okullarında öğrencilere yönelik özel görevler hazırlama konusunda uygulamalar yapmaya teşvik edilmelidir.

\section{Kaynaklar}

Ayers, D.J. (2008). The effect of teacher attitudes on differentiated instruction two rural elementary schools in Monroe Country, Georgia. Yayımlanmamıs doktora tezi. USA: Capella University.

Bravmann, S. (2004). Two, four, six, eight, let's all differentiate differential education: Yesterday, today, and tomorrow. 10 Temmuz 2016 tarihinde http://www.newhorizons.org/strategies/differentiated/bravmann.htm adresinden alınmıştır.

Brennan, S.A. (2008). Differentiated instrbuction and literacy skill development in the preschool classroom. Yayımlanmamış doktora tezi. Iowa: Iowa State University Ames.

Büyüköztürk, Ş. (2002). Sosyal bilimler için veri analizi el kitabl. Ankara: Pagema

Chapman, C., \& King, R. (2003). Differentiated instructional strategies for reading in the content areas. California: Carwin Pres, Inc.

Çam, Ş.S. (2013). Öğretmenlerin farklılaştırılmış ögretim yaklaşımını uygulama ve buna ilişkin yetkinlik düzeyleri. Yayımlanmamış doktora tezi. Türkiye: Eskişehir Osmangazi Üniversitesi, Eğitim Bilimleri Enstitüsü.

Driskill, K.M. (2010). A qualitative study of teacher understanding and use of differentiated instruction to promote reading achievement. Yayınlanmamıs doktora tezi. Phoenix: University of Phoenix.

Garcia, O. (2011). Educating New York's bilingual children: Constructing future from thepast. International Journal of Bilingual Education and Bilingualism, 14(2), 133-153.

Hall, T. (2002). Differentiated instruction. 29.06.2016 tarihinde www.cast.org/publications/ncac/ncac-diffinstruc.html adresinden alınmıştır.

Heacox, D. (2002). Differentiating instruction in the regular classroom: How to reach and teach all learners, grades 3-12. ABD: Free Spirit Publishing.

Lavender, D.R. (2009). The effect of in-class behavioral intervention plus differentiated instruction program on the achivement and behavior outcomes of verbally disruptive 8th-grade students with and without co-occurring reading delimitation. Yayınlanmamış doktora tezi. USA: The University of Nebraska. 
Samms, P. (2009). When teachers differentiate reading instruction for fifth grade students: impact on academic achivement, social and personal development. Yayınlanmamış doktora tezi. Sarasota: Argosy University.

Smutny, J.F. (2003). Differentiated instruction. Phi Delta Kapa Fastbacks, 506, 7-47

Kahyaoğlu, M. ve Yangın, M. (2007). İlköğretim öğretmen adaylarinin mesleki özyeterliklerine ilişkin görüşleri. Kastamonu Eğitim Dergisi 15(1), 73-84

Karadağ, R. (2014). Dünyada ve Türkiye'de farklılaştırılmış öğretimle ilgili yapılmış çalışmaların değerlendirilmesi. Kastamonu Eğitim Dergisi 22(3), 1301-1322

Karasar, N. (2005). Bilimsel arastırma yöntemi. Ankara: Nobel Yayin Dağıtım.

MEB (2008). Okulöncesi Öğretmen Özel Alan Yeterlikleri. 11 Temmuz 2016 tarihinde http://otmg.meb.gov.tr/belgeler/alanyeterlikler/okul\%20\%C3\%B6ncesi\%20\%C3\%B6\% C4\%9Fretmeni\%20\%C3\%B6zel\%20alan\%20yeterlikleri.pdf adresinde alınd.

MEB (2013). Okulöncesi eğitim programı. Ankara: Talim Terbiye Kurulu Başkanlığı

Prater, M.A. (2003). She will succeed! Strategies for success in inclusive classrooms. Teaching Exceptional Children, 35, 58-64.

Richards, M.R.E., \& Omdal, S.N. (2007). Instruction on academic performance in a secondary science course. Journal of Advanced Academics, 18(3), 424-453.

Tomlinson, C. A. (2005). Grading and differentiation: paradox or good practice? Theory into practice. 44(3), 262-269

Whipple, A.K. (2012). Differentiated instruction: A survey study of teacher understanding and implementation in a southeast Massachusetts school district (Doctoral dissertation). Retrieved from ProQuest Dissertations and Theses. (UMI no. 3525802).

Woolfolk, A.E. (1998). Educational psychology, Allyn and Bacon Pub.

Yabaş, D. ve Altun, S. (2009). Farklılaştırılmış öğretim tasarımının öğrencilerin öz-yeterlik algıları, biliş üstü becerileri ve akademik başarılarına etkisinin incelenmesi, Hacettepe Üniversitesi Ĕ̈itim Fakültesi Dergisi, 37, 201-214.

\section{Extended Abstract}

\section{Introduction}

Children are different from each other. Each of them has different family culture, different prior knowledge and different personality traits. For this reason, education must differentiate for each student in order to care for the individual differences. In recent years, education based on individual differences has come to the forefront because the developed programs are based on constructivism.

Generally, studies on Differentiated Education have intensified on measuring the perception levels of the teachers, and on the influence of this system on students. This study, on the other hand, was conducted with preschool teacher candidates, who will be assigned to active duties in preschool educational institutions where individual differences play major roles. Differentiated Education is one of the approaches that overlap with the paradigms of the new programs.

The purpose of this study is to investigate and reveal the self-efficiency levels of the preschool teacher candidates studying at the Educational Faculty of a Foundation University in Differentiated Education based on their viewpoints. For this purpose, answers to the following questions have been sought:

1. What are the viewpoints of the preschool teacher candidates on their self-efficiency in Differentiated Education?

2. Are there any differences between the viewpoints of the preschool teacher candidates on Differentiated Education in terms of their grades?

3. Are there significant differences between the viewpoints of the preschool teacher candidates on their self-efficiency in Differentiated Education according to their having received training on Differentiated Education? 
4. Are there any significant differences between the viewpoints of the preschool teacher candidates on their self-efficiency in Differentiated Education according to whether they have read books on Differentiated Education or not?

It is considered that the results of the study will provide beneficial data for teachers and academicians, who will work in this field. Especially, knowing the self-efficiency levels of the preschool teacher candidates, who will use the Differentiated Education at schools in our present day on which the education intended for the preschool students have gained much importance, will guide many stakeholders in the field of education.

\section{Method}

Since the existing status of the teacher candidates on the usage levels of the Differentiated Education have been aimed to be determined in the study, the Scanning Method was used. The universe of the study consists of the 120 preschool teacher candidates studying at the Educational Faculty of a Foundation University in Istanbul in 2015-2016 Academic year. 96 volunteering teacher candidates were included in the study. The Quantitative Data Analysis was used in the study, and the data were collected with the "Differentiated Education Questionnaire", which was developed by the author of the study. The validity and reliability works of the questionnaire were performed in the light of specialist viewpoints and the results of pre-application. First of all, a literature scan was performed in order to determine the usage levels of the Differentiated Education by preschool teachers, and a group of teachers was interviewed face-to-face. Open-ended questions were asked to the teachers to determine their usage of the Differentiated Education.

The first part of the data collection tool consisted of personal information. The personal information section included information like grades, participation to training on Differentiated Education, reading books/publications on Differentiated Education, etc. In the second section, there was a questionnaire consisting of 17 questions aiming to determine the usage levels of the Differentiated Education. The questionnaire was graded as "No" (1), "A little" (2), "Yes" (3) in 3-Point scale. Each item was evaluated as independent from each other. For this reason, an analysis like Cronbach Alpha Internal Consistency was not used for the reliability of the test. The data in the study were analyzed with frequency, percentage, arithmetic averages, and ChiSquare.

\section{Findings and Discussion/Results}

According to the results of the study, the preschool teacher candidates consider themselves as sufficient in many of the items of Differentiated Education. The preschool teacher candidates find themselves as being insufficient in some parts of the application of the Differentiated Education. They consider themselves as being insufficient in items such as preparing educational activities for upper-level students, layering the class according to students from each level, motivating all students, preparing plans by receiving the opinions of the students.

It was observed in the study that there were significant differences between the status of the preschool teacher candidates according to receiving seminars, conferences, etc. on Differentiated Education, having read books-publications, and using self-efficiency in Differentiated Education. In this context, teacher candidates, who received conference, seminars, courses etc., considered themselves as being more efficient on Differentiated Education than those who did not receive any seminars or courses in areas such as planning and preparing educational activities according to the student's opinions, according to slow-learners, and upper-level students. In addition, the teacher candidates, who received conference, seminars, courses etc., on Differentiated Education, considered themselves more efficient on guiding students in real life problems in which different disciplines are used together than those who did not receive such seminars or courses. It is possible to claim that the teacher candidates, who read books-publications on Differentiated Education considered themselves as being more efficient on motivating all students in an equal manner, performing activities by caring for the 
speed of learning of each student, planning educational activities for upper-level students, on guiding students in real life problems in which different disciplines are used together than those who did not read books-publications on Differentiated Education.

The topics in which the preschool teacher candidates feel themselves as being insufficient must be provided in the curriculum. The topics such as preparing educational activities for upper-level students, how to layer the classes for students of different levels, how to motivate all students, how to prepare plans for receiving the opinions of the students must be especially included in the curriculum of the "Teaching Principles and Methods, Developing Individualized Education Programs" classes.

Since some of the preschool teacher candidates, who received conferences, seminars, courses, etc., considered themselves as being more sufficient, applicable training with the sponsorship of various organizations must be organized for preschool teacher candidates on how to plan educational activities for slow learners and upper-level students by receiving students' opinions.

Preschool teacher candidates must be encouraged to read books-publications on motivating all students, performing activities by caring for the speed of learning of each student, planning educational activities for upper-level students, and on guiding students in real life problems in which different disciplines are used together.

Preschool teacher candidates must also be encouraged to apply specific tasks for the students in their internship schools. 